\title{
REORGANISATION OF THE SOUTH AFRICAN NURSING ASSOCIATION AND \\ THE IMPLICATIONS THEREOF
}

Paper presented at the symposium

Is a professional Association the answer?

\section{PROF. P. HARRISON}

\section{Head of the Department of Nursing, University of Cape Town; Out-going Vice-President, South African Nursing Assocation}

\section{OPSOMMING}

Die eerste organisasle van verpleegkundiges in Suid-Afrika was die Suid-Afrikaanse Vereniging vir Opgeleide Verpleegsters. Lidmaatskap was vrywillig en die Vereniging het swaar gedra aan die las van die hele beroep. Die SuidAfrikaanse Verpleegstersvereniging, met verpligte lidmaatskap. het in 1944 tot stand gekom. Die sake van die Vereniging is behartig deur 'n Blanke bestuur en Adviserende Komitees vir die ander bevolkingsgroepe.

Die Bestuur van die Vereniging het ' $n$ algemene gebrek aan belangstelling in hul professionele organisasie onder verpleegkundiges waargeneem - 'n nuwe benadering, wat meer betrokkenheid aan die hand sou werk, was nodig. Die nuwe grondwet tree nou in werking waarvan die volgende die belangrikste beginsels is:

- desentralisasie deur streeksbesture;

- direkte verteenwoordiging van alle bevolkingsgroepe op die besture en verteenwoordiging van verpleegkundiges uit verskillende sektore;

- 'n Sentrale Bestuur met verteenwoordiging uit elke streek.

Die implikasies van die herorganisasie is verreikend maar die huidige Bestuur het die volste vertroue in die verpleegkundiges van die land om 'n sukses daarvan te maak.

\section{HISTORICAL PERSPECTIVE}

There is value in taking an historical perspective - it helps to gauge the subject in the present day situation and provides information on how our nursing ancestors attempted to obtain solutions and answers to the problems of their times.

In South Africa at the turn of the century there were quite a number of British nurses, as well as some South Africans, who were members of the Royal British Nurses' Association. It could however hardly be expected that the RBNA could do much for professional problems of nurses in South Africa and no attempt was made to form a South African branch. Sister Hirst Watkins, friend of Sister Henrietta, was of the opinion that a South African Nurses' Association should be formed but died before this idea could be developed. Then Miss Hannah, an uncertificated nurse came on the scene and, with a group of nurses, formed a South African Nursing Association in 1905. She and her colleagues made some progress but their objectives clashed with the existing legislation for registration of nurses and Sister Henrietta opposed the idea as formulated. Miss J.C. Child and Sister Henrietta preferred the idea of an independent South African Nursing Association whose activities would not clash with the Medical Councils' statutory responsibilities for the registration of nurses. Sister Henrietta died in 1911 before much progress was made.

Matters really started moving when Mr. C.J. Smith, who owned a Printing Works in East London, was approached by his friend $\mathrm{Dr}$. John Tremble to publish a journal to be called The S.A. Nursing Record and in October 1913, the first professional nursing journal (edited by Dr. Tremble) saw the light of day. His editorials were a great challenge to the many nurses practising throughout the country and motivated the nurse leaders of those far-off days to strive for a truly professional association. A Provisional Committee was elected consisting of influential nurses who were to lay the foundations for this infant association. The aims which they formulated, were as follows:

1. To weld the nurses of South Africa into one united band of workers.

2. To encourage co-operation and to take united action in the protection of the interests of the profession.

3. To encourage and in every way maintain the highest ideals of nursing in South Africa.

4. To hold social and professional gatherings whenever necessary or expedient, to discuss all matters pertaining to or affecting the interests of the profession.

5. To take such steps towards the 
formation of Benevolent Funds or Pension Schemes as may be thought necessary.

6. To become more actively united by means of similar nurses' organisations in other countries with the members of the profession throughout the world.

7. To take all possible steps to suppress the practice of nursing by unqualified women and to prevent abuse of the nurse's uniform. (Searle, 1965 p. 242)

The logical development was to form branches in the main centres throughout the country (this included Rhodesia, Basutoland and Bechuanaland).

The branches elected members to the Central Committee, later to be called the Central Governing Board. Two eminent doctors of the time, Dr. Tremble and Dr. Ronald Mackenzie, who were deeply interested in the nursing profession, were elected as Advisory Members. This link with their medical colleagues was to assist the nurses enormously.

That was how the professional organisation of South African nurses was launched. Of course mistakes were made and with hindsight one often wonders how these mistakes could have happened. Membership was for instance only open to trained female nurses. There also seemed to be a strong feeling that the matrons of the larger hospitals dominated the Association. (Aren't these same remarks heard sixty years later? Today the complaint is however not against matrons but against the Professors of Nursing).

From the beginning, the South African Trained Nurses' Association concerned itself with the socioeconomic welfare of nurses and their working conditions. Membership was however voluntary and it was indeed an uphill struggle for the dedicated few to carry the load of the whole profession. No doubt, the non-members were very vocal in their criticism and yet were perfectly content to reap the benefits of the negotiations so painstakingly undertaken by the South African Trained Nurses' Association.

The next big milestone in the professional organisation's growth was of course, the passing of the
Nursing Act 45 of 1944 when two statutory bodies, the South African Nursing Council and South African Nursing Association were created. As far as the Association was concerned, it now had compulsory membership and student nurses were included as junior members. Statutory Biennial Congresses were held and nurses had the opportunity to debate their problems and formulate policies which would ensure the growth and advancement of nursing in the post-war years. Admittedly some of the resolutions that cropped up congress after congress were of a somewhat petty, domestic nature, but time was needed to wean some branch members away from their rather parishpump mentality. The Association as a whole was endeavouring to develop a really strong dynamic body, controlled by nurses, who worked together for an adequate and efficient nursing service for the people of South Africa - a strong body, that had muscle, to negotiate with employing bodies and the Public Service Commission.

\section{THE PRESENT}

Since 1957 the Association has been functioning through a Board and the Branches. The Board was elected by White members, except for three White Board members appointed by the Advisory Committees of the Black, Coloured and later Indian members. Congresses have been held, latterly triennially, and in most instances, a much more mature approach to the affairs of nurses has become evident. Those hardy annuals (resolutions about shoe allowances and cool uniforms) are no longer debated ad nauseam. While the Board Report remained an integral part of any Congress, interesting and important papers based on an agreed theme were also included as part of the proceedings.

Discussion groups linked to various Branches were also constituted and this was undoubtedly a healthy development. Nurses with special interests and skills obviously wished to meet on a regular basis and discuss advances and developments in their fields of specialisation. Very often it was these discussion groups that initiated refresher courses, symposia and seminars. Nurses realised the importance, and their professional responsibility, of keeping themselves and interested colleagues up-dated and abreast of developments.

There was unfortunately a tendency among many branch members to concentrate on their discussion group activities at the expense of the parent branch activities. Throughout the country there were excellent attendances at discussion group meetings, while a handful of the faithful few carried the responsibility of Branch matters - often with a bare quorum. Apathy? Noncommitment? Indifference? The election polls for Board elections were alarmingly low. Too many nurses seemed perfectly content to let someone else do the job. Yet the talent was there, as was evident from the success of the discussion groups. Was it because the members could identify with smaller groups and saw opportunities for their potential growth in a known environment? The business side of running their professional organisation just did not seem to interest the majority of members.

\section{THE FUTURE}

The present Board took serious cognisance of the waning interest amongst so many nurses towards their professional organisation. It was quite obvious that a totally new approach, that would ensure direct involvement at grass-root level, had to be planned. A new Constitution was drafted and through various Congresses the profession as a whole was invited to comment, amend, re-design and debate fully the pros and cons of the draft. The new Constitution has now become a fact of life. It is the responsibility of the present and future generations of nurses to breathe life into this, at present, skeletal frame.

\section{What are the main principles of the new Constitution?}

\section{Regionalisation}

South Africa has been divided into seven regions and each region will have its own Regional Board. This will ensure representation by nurses with a sound knowledge of local 
problems, their members' worries, concerns and aspirations and firsthand contact with members of the other caring professions and the authorities.

\section{Guaranteed Representation of:}

- various population groups, which hopefully will assist the profession to speak with one voice;

- the main branches of nursing thus avoiding the past complaints that certain categories dominated the Association. Nurses in the public service, education and the private sectors now have the opportunity of making a unique contribution. Each section will bring its specific expertise and experience to the Regional Board.

\section{Central Board}

This is constituted in such a way that every region has guaranteed representation on this body. Those matters which concern the profession on a nationwide basis will be dealt with by the Central Board.

\section{Branches}

Branches will be constituted as previously, but there will be a much closer and more personal link between the branches in a region and their own Regional Board.

\section{THE IMPLICATIONS}

The implications of the reorganisation of the South African Nursing Association are far-reaching and should guarantee the constant growth of the professional organisation. Many more nurses are going to be directly and personally involved in their own professional growth. No longer can the statement be made that a handful of old nurses, in Pretoria and out of touch with the practical situations, make decisions for the silent majority. The ball is right back in the court of the average member. She, through her Regional Board, is going to manage the affairs of the Association in her area (except for those matters which shall be managed at central level). Her Regional Board will trace all nurses in her area, act as spokesman for nurses and midwives in her area, promote the socioeconomic and other interests of the profession, identify health needs, maintain the integrity and raise the status of the profession and develop an adequate and effective nursing and midwifery service for its area through professional and educational development of its members.

The present Board has complete faith and confidence in the nurses of South Africa and is convinced that they will rise to the challenge. It is going to take some time for the new approach in the reorganised Association to be fully appreciated and to bear fruit. There are going to be teething troubles. With patience, sound communications and tolerance, however, the newly designed Association will be a success. It depends on each and everyone to see that this is realised.

REFERENCE

SEARLE. C The History of the Development of Nursing in South Africa 1652-1960. Struik. Cape Town 1965.

\section{BOOK REVIEW BOEKRESENSIE}

\section{PLANNED HOME CHILDBIRTHS}

\section{Mary Conklin and Ruth Simmons. Michigan De- partment of Public Health. 1980.}

Beplande tuisbevallings, ooglopend in uiters subjektiewe aangeleentheid, word in Amerika deur 'n meerderheid vroue (verwagtende moeders) aanbeveel. indien nie selfs op AANGEDRING nie. Die aangeleentheid is nie summier buite sekere state se jurisdiksie nie.

Die skryfsters gee verslag oor 'n taamlike intensiewe navorsingsprojek wat in die laat sewentigerjare geloods is om beplande tuisbevallings versus hospitaalbevalling op die weegskaal te plaas.

'n Volledige vraelys vir insae in die tuisbevalling is agter in die boekie te vinde. Baie medewerkers het opi- nies gelig en voor en nadele is goed bespreek.

Carlson en Sumner (bls 88) praat van special Lamaze trained nurses van die Manchester Memorial Hospital in Connecticut wie se doelwit dit is om 'n balans te handhaaf tussen die mediese en emosionele aspekte van baring.

Persoonlik dink ek die ge-emansipeerde vrou gaan soveel druk uitoefen dat die Lamaze droom binne die volgende twee dekades verwesenlik gaan word. Hier is 'n uittreksel uit die brief van "n vrou - But hospitals are particulary messed up and I didn't want to bring a child into the world in a cold, sterile, germfree, profit orientated, inhumane, impersonal place that a hospital is. (bis 27). Hierdie is stof tot nadenke omdat dit nie "n geisoleerde mening is nie.

Mev. H.S. Pieri 